\title{
Crime prevention based on the strategic mapping of living con- ditions
}

\author{
Nicklas Guldåker ${ }^{1 *}$, Per-Olof Hallin ${ }^{2}$, Kim Nilvall $^{3}$ and Manne Gerell ${ }^{4}$ \\ 1 Department of Human Geography, Lund University, Sweden; Nicklas.guldaker@keg.lu.se \\ 2 Department of Urban Studies, Malmö University, Sweden; per-olof.hallin@mau.se \\ 3 Swedish National Bureau of Investigation - Intelligence section, organised crime; kim.nilvall@polisen.se \\ 4 Department of Criminology, Malmö University, Sweden; manne.gerell@mau.se \\ * Correspondence: Nicklas.guldaker@keg.lu.se
}

\begin{abstract}
This paper presents a theoretically and methodologically grounded GIS-based model for the measurement and mapping of an index of living conditions in urban residential areas across Sweden. Further, the model is compared and evaluated using the Swedish Police's assessment of crime-exposed areas. The results indicate that geographically measured vulnerable living conditions overlap to a large extent with the areas assessed to be crime-exposed by the Swedish Police. Over $61 \%$ of the police-defined crime-exposed areas are characterized by vulnerable living conditions. The results also show that the overlap is not perfect and that there are vulnerable areas that are not included in the police's assessment of crime-exposed areas, but which are nonetheless characterized by vulnerable living conditions that could negatively affect the development of crime. It is also proposed that the model and the mapped index of living conditions provide a more wellgrounded scientific basis for the police's assessment work. As a first step, the Swedish police have implemented the model and the mapped index in the work process employed in their annual identification of crime-exposed or at-risk areas. In addition to assisting the police, the model and the mapped index could also be used to support other societal actors working with vulnerable areas.
\end{abstract}

Keywords: living conditions; crime prevention; crime-exposed areas; strategic mapping

\section{Introduction}

People's living conditions are of fundamental importance for their developmental opportunities, particularly among children. Living conditions may be determined by different factors such as the family situation, relationships with and support from the surrounding community, financial conditions, and the health of people living in different residential areas. Unequal living conditions affect various aspects of life [1], e.g. health [2], school results [3,4], and exposure to crime [5]. Previous research has identified variables such as educational level, employment rate, income, foreign background, single-parent households, the number of children and adolescents in different age groups, and overcrowding as strong indicators of different levels of living conditions [6-9]. Early criminological research indicated that areas characterized by vulnerable living conditions were also more vulnerable to crime [10-16]. However, vulnerable areas are exposed to crime to a varying extent. Some areas have high rates of both violent and other crime, while others do not differ significantly from non-vulnerable residential areas.

Assessments of crime-exposed areas are usually based on statistics [17]. However, complementary geographical methods may also be important for the police's and other actors' assessments of crime-exposed areas. Area assessments based on maps, sketch maps, hotspots of crime and socio-economic disadvantage are relatively common worldwide. These methods have been employed in order to e.g. increase police knowledge of the areas in which they patrol $[18,19]$, or present and compare police and public perceptions of crime in different neighborhoods [20-22]. Studies show that there are differences 
between the perceptions and assessments of the police and other residents $[23,24]$, and they also demonstrate a need for more scientifically grounded approaches to supplement experience-based and more subjective assessments of crime-exposed urban areas [25]. In Sweden, the Swedish Police have assessed and defined 60 crime-exposed areas, in which citizens' exposure to crime has a strong impact on their daily lives in the local community [26]. Other crime-exposed areas have also been identified and reported by local police organizations, and there are now a total of over 180 crime-exposed areas in Sweden. However, the mapping and demarcation of these areas is still primarily based on individual police officers' experiences and perceptions of the residential areas in question.

The purpose of this paper is to present and apply a theoretically and methodologically grounded GIS-based model for the measurement and mapping of an index of living conditions in urban residential areas across Sweden, and further to compare and evaluate this approach in relation to the Swedish Police's assessment of local problem areas and crime-exposed areas. The model and the map of indexed living conditions developed in this paper are presented and analyzed in relation to two related, but independent, geographical datasets comprised of 1) local problem areas assessed on the basis of an operational police perspective, and 2) vulnerable areas identified on the basis of socio-economic status. One objective in developing the model, and its application in the form of a national database and web map, is that this will form the basis for further analyses of living conditions in various areas.

\section{Materials and Methods}

\subsection{Material}

The socio-economic and demographic data used to index living conditions have been collected from Statistics Sweden (SCB). The statistical data are mapped onto $250 \times 250$ meter grids that cover mainly urban areas across Sweden with more than 200 inhabitants. The indexation of living conditions is based on the following variables:

- $\quad$ Education - Pre-upper-secondary education (\% of pop.)

- $\quad$ Employment rate - Employed persons aged 20-64 (\% of pop.)

- Income - Net median income 20+ years (SEK)

- $\quad$ Foreign background - Population of foreign background (\% of pop.)

- $\quad$ Marital status - single parents with children still living at home (\% of pop.)

- $\quad$ Population per square kilometer $\left(\mathrm{pop} / \mathrm{km}^{2}\right)$

In addition to the socio-economic and demographic data, the study employs a dataset comprising the Swedish Police's own assessment of crime-exposed local problem areas (LPAs) from an operational police perspective. Based on a structured assessment, each local police district has been required to manually delineate problem areas on a map and report them to the national police level. This first assessment resulted in over 180 mapped polygons across urban and rural areas throughout Sweden. In the current study, this data set is used primarily to illustrate LPAs in central parts of cities.

Another police dataset employed in the article, which in part overlaps with the LPAs, is the National Operations Department's (NOA) assessment of areas exposed to crime. This national assessment is based on the local police areas' annual reporting, which is in turn produced using a structured, stepwise assessment method divided in four parts [26]. The overall assessment is mainly carried out from a police perspective, with a specific focus on citizens' exposure to crime and criminal networks and their impact on local communities [8,26]. Approximately 60 such crime-exposed areas were identified in 2019. However, this number changes over time depending on the results of the assessment and developments in the relevant areas' crime levels. Another tendency is that these crimeexposed areas are not evenly distributed across Sweden's local police districts. Instead they tend to be concentrated in certain (metropolitan) areas in the southern parts of Sweden, and many of these are stable over time (Figure 1). 
In its assessment, NOA employs three different categories: exposed areas; particularly exposed areas; and risk areas. These areas are described as follows:

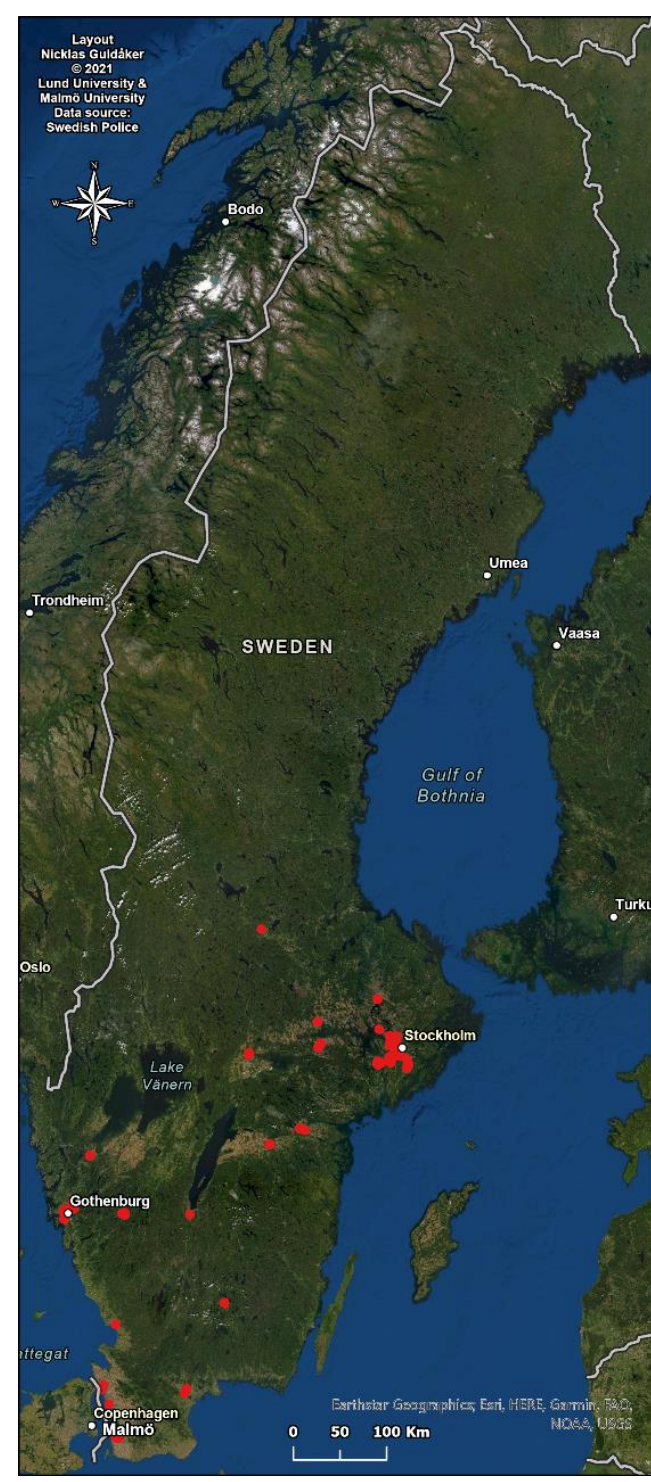

Figure 1. Areas assessed to be crimeexposed in Sweden, 2019.
- An exposed area is a geographically defined space, characterized by low socio-economic status, in which criminal actors have an impact on the local community. This impact can be exerted via direct pressure on people, organizations, and businesses, for example via threats and extortion, or indirectly via acts of public violence that risk harming thirdparty citizens, open drug trafficking, and a dissatisfaction with societal institutions. In consequence, residents in the exposed area may experience insecurity and fear, which leads to a reduced tendency to report crime and to participate in the legal process. The situation is considered serious.

- In a particularly exposed area, the situation is even more serious. From a police perspective, such areas are characterized by a general reluctance among the populations to participate in legal proceedings. There are also systematic threats and acts of violence against witnesses, injured parties, and those who oppose criminals. The situation in these areas makes it almost impossible for the police to carry out their mission. The serious situation also tends to become normalized. Residents and other actors no longer reflect on the fact that the area is different from other areas. Particularly exposed areas are further characterized by pronounced features of parallel social structures and extremism, e.g. systematic violations of religious freedoms or powerful fundamentalist influences that restrict human rights and freedoms. These areas may also have residents who travel abroad to participate in armed conflicts and a high concentration of criminals. In addition, the presence of several adjacent particularly exposed areas poses a greater risk of more geographically widespread criminal activities and networks.

- Risk areas constitute an intermediate level between exposed and particularly exposed areas. The situation is serious, and there is a risk that the area will become a particularly exposed area if no efforts are made to curb this development. Negative developments in a risk area can be prevented if adequate measures are implemented [26].

It should be emphasized that the assessment of exposed areas from a police perspective, including all three categories above, has been carried out completely independently of the modeling and mapping of living conditions presented in this paper. It should also be emphasized that the concept exposed area is used in the paper, with some exceptions in the analysis, as a generic term for all three categories. 
The base map employed in the paper comprises: ESRI, Maxar, GeoEye, Earthstar Geographics, CNES/Airbus DS, USDA, USGS, AeroGRID, IGN, and the GIS User Community; Sources: Esri, Here, Garmin, FAO, NOAA, USGS, @ Open StreetMap Contributors, and the GIS User Community.

\subsection{Methods}

The indexation of living conditions has been conducted in four principal steps involving intermediate indices of: a) family conditions; b) housing (segregation) conditions; and c) economic conditions (see Figure 2). The four steps are as follows:

1. Each of the variables presented earlier (education, employment rate, income, foreign background, single parents with children still living at home, and population per square kilometer) were divided into five numeric classes, with the values in the lowest class being converted to the value 1 , and with those in the highest class being given the value 5 (see Table 1). An example is the division of the income variable into five classes. This division is based on Statistics Sweden's official division of income intervals by purchasing power: B1 - population 20 years or older after aggregate acquired income in quartiles (gross income before tax): Quartile 1: 0 - 163,617 SEK; Quartile 2: 163,618 - 280,169 SEK; Quartile 3: 280,170 - 400,577 SEK; and Quartile 4: SEK 400,578 SEK or more [27]. In addition to the four quartile classes, a fifth class has been added for those with an income of more than SEK 500. The lowest income class is assigned the value 1, the second lowest the value 2, and so on. All variables, intermediate indices, classification methods, the number of grids for each variable and the motivation of classes and data sources are presented in Table 1.

2. The variables were then combined into three intermediate indices - Family, Housing and Economic conditions - by adding the classified values for all variables included in a given index and then dividing by the number of variables. For example, the intermediate index for Economic conditions is calculated as follows: The values for the variables education, employment rate and income were summed, and then divided by 3 . The maximum value per mapped $250 \times 250$ meter grid - corresponding to good economic conditions in our model - is therefore $5((5+5+5) / 3)$. The lowest possible value per grid vulnerable (or poor) economic conditions - is $1((1+1+1) / 3)$. The intermediate indices for Housing (segregation) conditions (variable: foreign background) and Family conditions (variables: overcrowding - population per $\mathrm{km}^{2}$; single parents with children still living at home) were calculated in the same way.

3. The final living conditions index was calculated in the same way; the values of all three intermediate indices were given the same weight and then added and divided by 3 . The index values for different levels of living conditions were then classified in the range between 1 and 5. Since the index values are normally distributed, the classification and mapping has been based on standard deviations from the mean value (Figure 3).

4. The mapped living conditions index was then overlaid onto the two policedefined datasets.

All calculations and mapping operations have been performed in ArcGIS pro versions 2.5.0 and 2.6.0. 


\begin{tabular}{|c|c|c|c|c|c|}
\hline $\begin{array}{l}\text { Intermediate } \\
\text { description }\end{array}$ & Variable & $\begin{array}{l}\text { Classification method and } \\
\text { classes }\end{array}$ & $\begin{array}{l}\text { No. of } \\
\text { grids }\end{array}$ & $\begin{array}{l}\text { Statement/motivation of } \\
\text { classes }\end{array}$ & $\begin{array}{l}\text { Source and } \\
\text { comments }\end{array}$ \\
\hline \multirow[t]{3}{*}{$\begin{array}{l}\text { Economic } \\
\text { conditions }\end{array}$} & $\begin{array}{l}\text { Education - Pre- } \\
\text { upper-secondary } \\
\text { education }(\%)\end{array}$ & $\begin{array}{l}\text { Classification based on } \\
\text { mean and standard } \\
\text { deviations (normal } \\
\text { distribution), rounded to } \\
\text { the nearest integer, mean } \\
\text { value }=12.7 \\
\text { Class } 1 ;>49 \\
\text { Class } 2: \leq 49 \\
\text { Class } 3 \leq 23 \\
\text { Class } 4: \leq 10 \\
\text { Class } 5:>3\end{array}$ & 85,632 & $\begin{array}{l}\text { The lower the level of } \\
\text { education, the greater the risk of } \\
\text { economic marginalization }\end{array}$ & $\begin{array}{l}\text { Statistics } \\
\text { Sweden (SCB) } \\
\text { Year of } \\
\text { collection: } 2018\end{array}$ \\
\hline & $\begin{array}{l}\text { Employment rate } \\
(\%)\end{array}$ & 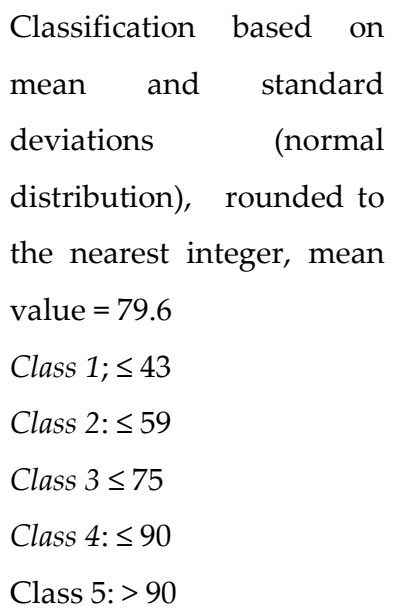 & 81,672 & $\begin{array}{l}\text { The lower the employment rate, } \\
\text { the greater the risk of economic } \\
\text { marginalization }\end{array}$ & $\begin{array}{l}\text { Statistics } \\
\text { Sweden (SCB) } \\
\text { Year of } \\
\text { collection: } 2018\end{array}$ \\
\hline & Income (SEK) & $\begin{array}{l}\text { Quartiles }+1 \text { extra class, } \\
\text { mean value }=269,995 \\
\text { Class } 1 ; \leq 163,617 \\
\text { Class } 2: \leq 280,169 \\
\text { Class 3: } \leq 400,577 \\
\text { Class } 4: \leq 500,000 \\
\text { Class 5: }>500,000\end{array}$ & 94,612 & $\begin{array}{l}\text { The lower the income, the } \\
\text { greater the risk of economic } \\
\text { marginalization }\end{array}$ & $\begin{array}{l}\text { Statistics } \\
\text { Sweden } \\
\text { Year of } \\
\text { collection: } 2016\end{array}$ \\
\hline $\begin{array}{l}\text { Family } \\
\text { conditions }\end{array}$ & $\begin{array}{l}\text { Marital status - } \\
\text { singe parents (\%) }\end{array}$ & $\begin{array}{l}\text { Classification based on } \\
\text { mean and standard } \\
\text { deviations (values not } \\
\text { normally distributed), } \\
\text { rounded to the nearest } \\
\text { integer, mean value = 5.08 } \\
\text { Class } 1 ;>20 \\
\text { Class 2: } \leq 20 \\
\text { Class } 3 \leq 15 \\
\text { Class } 4: \leq 8 \\
\text { Class } 5: \leq 3\end{array}$ & 97,344 & $\begin{array}{l}\text { The higher the proportion of } \\
\text { single parents with children } \\
\text { living at home, the greater the } \\
\text { risk of vulnerable family } \\
\text { conditions }\end{array}$ & $\begin{array}{l}\text { Statistics } \\
\text { Sweden } \\
\text { Year of } \\
\text { collection: } 2018\end{array}$ \\
\hline
\end{tabular}




\begin{tabular}{|c|c|c|c|c|c|}
\hline & $\begin{array}{l}\text { Population per } \\
\mathrm{km}^{2}\end{array}$ & $\begin{array}{l}\text { Classification based on } \\
\text { mean and standard } \\
\text { deviations (values not } \\
\text { normally distributed), } \\
\text { rounded to the nearest } \\
\text { integer, mean value = } 1,303 \\
\text { Class 1; }>8,500 \\
\text { Class 2: } \leq 8,500 \\
\text { Class } 3 \leq 5,000 \\
\text { Class } 4: \leq 2,500 \\
\text { Class } 5: \leq 1,000\end{array}$ & 105,613 & $\begin{array}{l}\text { The higher the population } \\
\text { density, the greater the risk of } \\
\text { vulnerable family conditions }\end{array}$ & $\begin{array}{l}\text { Statistics } \\
\text { Sweden } \\
\text { Year of } \\
\text { collection: } 2018\end{array}$ \\
\hline $\begin{array}{l}\text { Housing } \\
\text { conditions } \\
\text { (segregation) }\end{array}$ & $\begin{array}{l}\text { Foreign } \\
\text { background (\%) }\end{array}$ & $\begin{array}{l}\text { Classification based on } \\
\text { mean and standard } \\
\text { deviations (values not } \\
\text { normally distributed), } \\
\text { rounded to the nearest } \\
\text { integer, mean value = } 15.6 \\
\text { Class 1; }>70 \\
\text { Class 2: } \leq 70 \\
\text { Class } 3 \leq 50 \\
\text { Class } 4: \leq 25 \\
\text { Class } 5: \leq 10\end{array}$ & 108,113 & $\begin{array}{l}\text { The higher the proportion of the } \\
\text { population with a foreign } \\
\text { background, the higher the risk } \\
\text { of segregation and vulnerable } \\
\text { housing conditions }\end{array}$ & $\begin{array}{l}\text { Statistics } \\
\text { Sweden } \\
\text { Year of } \\
\text { collection: } 2018\end{array}$ \\
\hline
\end{tabular}

\section{Theory}

The operationalization and indexation of living conditions for measurable geographical units is based on the theoretical and causal model presented in Figure 2. Living conditions are in this context generally defined as resources, relationships, and circumstances that affect the ability of individuals and groups to live an adequate and decent life [7]. This definition is quite open because living conditions can be difficult to measure holistically. A number of key socio-economic factors are therefore instead used as indicators of living conditions in terms of family, housing, and economic conditions.

Family conditions are very much about the care children receive (or do not receive) from their parents or in other relationships [8]. The measurable indicators we see that affect family conditions are marital status, and particularly if the parent is single with children still living at home, the number of children and adolescents in different age groups, and the level of overcrowding (yellow boxes in Figure 2). Foreign background is strongly linked to segregation and spatial differences in housing conditions in Swedish cities (blue boxes). Vulnerable housing conditions are also affected by high levels of overcrowding. Economic conditions can be operationalized by measuring the variables income level, degree of education and employment rate (gray boxes).

By measuring and mapping these three dimensions of living conditions, different levels of economic marginalization, segregation and vulnerable family and housing conditions can be identified across a geographical area. When these are in turn combined into an index (see methods section), it becomes possible to measure a scale ranging from vulnerable to good living conditions in different geographical areas. 
As shown in the theoretical model in Figure 2, there are additional influential dimensions that may be considered as indicators of living conditions. These include, for example, physical factors such as type of housing, the geographical isolation of an area, and access to services and public transport. We have not been able to incorporate these factors, however, due to the lack of national data on the geographical scale employed. Not all dimensions of living conditions can be easily measured, such as external and structural factors. As the model shows, these external and structural factors that exert influence include social polarization, structural conditions in the housing and labor markets, economic and democratic processes, global events with country-level effects, the regional context, and criminalizing processes and actions, such as open drug trafficking and increased violence against the police and citizens. Another influential dimension that is difficult to measure comprises the institutional capacities of the nation, the region, or the local community, and the collective efficacy of groups [15,28]. Important formal and informal institutional actors behind these capacities include e.g. municipal and regional administrations, the police, the emergency services, private schools, real estate companies, associations, and voluntary organizations. Although they are not included as measurable variables in this study, we would recommend that the above-mentioned dimensions that affect living conditions should be taken into account in more detailed studies of living conditions in specific geographical areas.

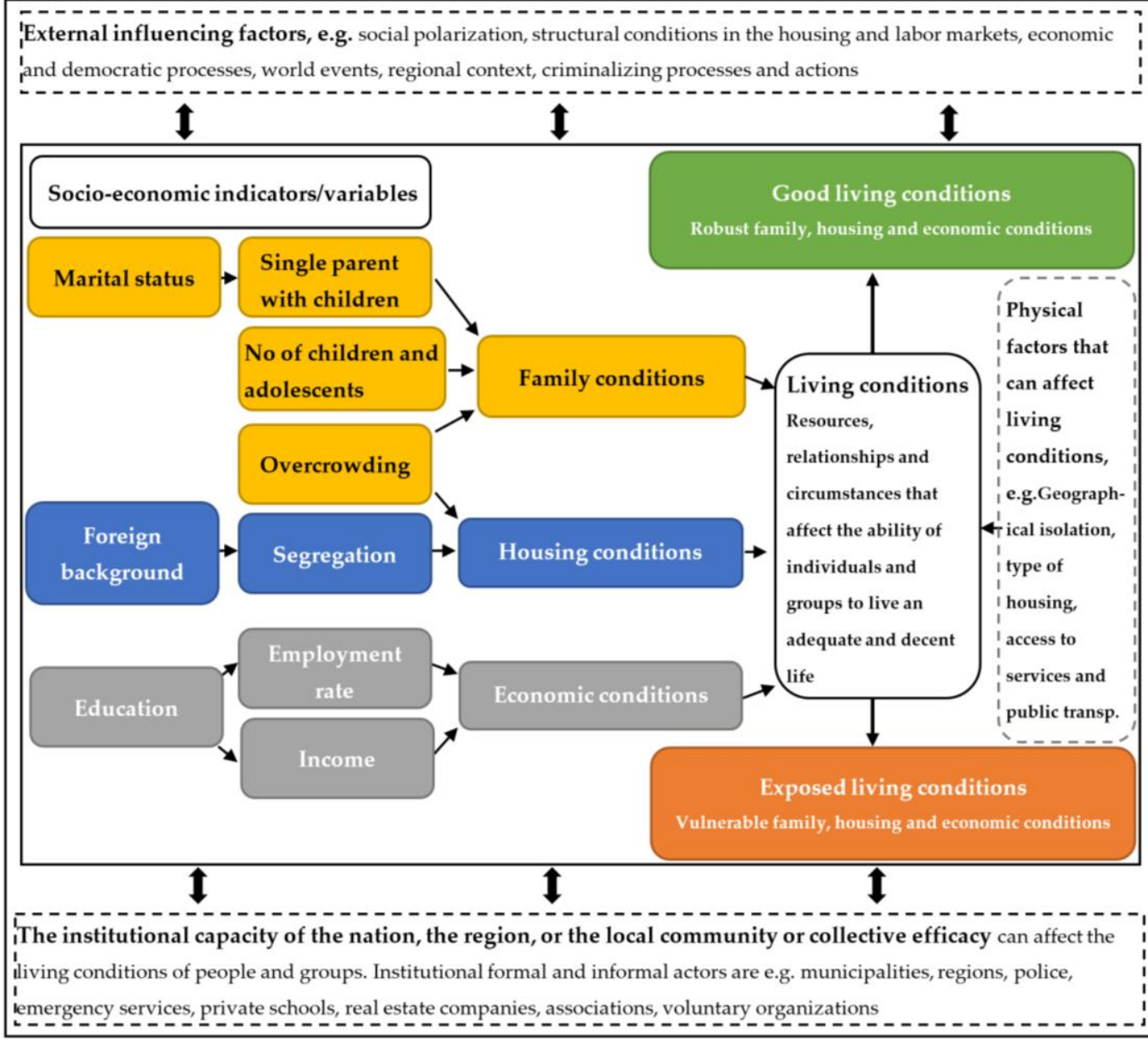

Figure 2. Theoretical and causal model of living conditions in a geographical area. The model also includes physical factors, external factors, and collective efficacy.

\section{Results}

The results from the classifications of the intermediate indices and the living conditions index are presented in Table 2. The number of indexed 250-meter squares across 
Sweden has been reduced from the maximum possible 108,113 to 69,567 due to non-overlapping socio-economic and demographic data. Despite this reduction, the mapping covers over 2,000 Swedish urban areas with a population of 200 or more. This is highly relevant given that $87 \%$ of Sweden's population lives in urban areas [29].

Table 2 Classification of intermediate indices and living conditions index

\begin{tabular}{|c|c|c|}
\hline Intermediate indices & Classification method and classes & No of grids \\
\hline $\begin{array}{l}\text { Economic } \\
\text { conditions }\end{array}$ & $\begin{array}{l}\text { Classification based on mean and standard } \\
\text { deviations (normal distribution), mean value }= \\
3.29\end{array}$ & 69,567 \\
\hline Family conditions & $\begin{array}{l}\text { Classification based on mean and standard } \\
\text { deviations (values are not normally } \\
\text { distributed), mean value }=4.16\end{array}$ & 69,567 \\
\hline $\begin{array}{l}\text { Housing conditions } \\
\text { (segregation) }\end{array}$ & $\begin{array}{l}\text { Classification based on mean and standard } \\
\text { deviations (values are not normally } \\
\text { distributed), mean value }=4.08\end{array}$ & 108,113 \\
\hline Living conditions & $\begin{array}{l}\text { Classification based on mean and standard } \\
\text { deviations (normal distribution), mean value }= \\
3.84\end{array}$ & 69,567 \\
\hline
\end{tabular}

The index values for living conditions turn out to be normally distributed across Sweden (Figure 3). These values have been divided and mapped into five classes based on standard deviations, with the class with values less than or equal to $(\leq)-2.0$ standard deviations from the mean value corresponding to areas with vulnerable living conditions (Figure 3 and Figure 4). Index values greater than (>) -2.0 standard deviations correspond to neighborhoods with good living conditions, while values more than 1.0 standard deviation above the mean, indicate living conditions that are particularly good.

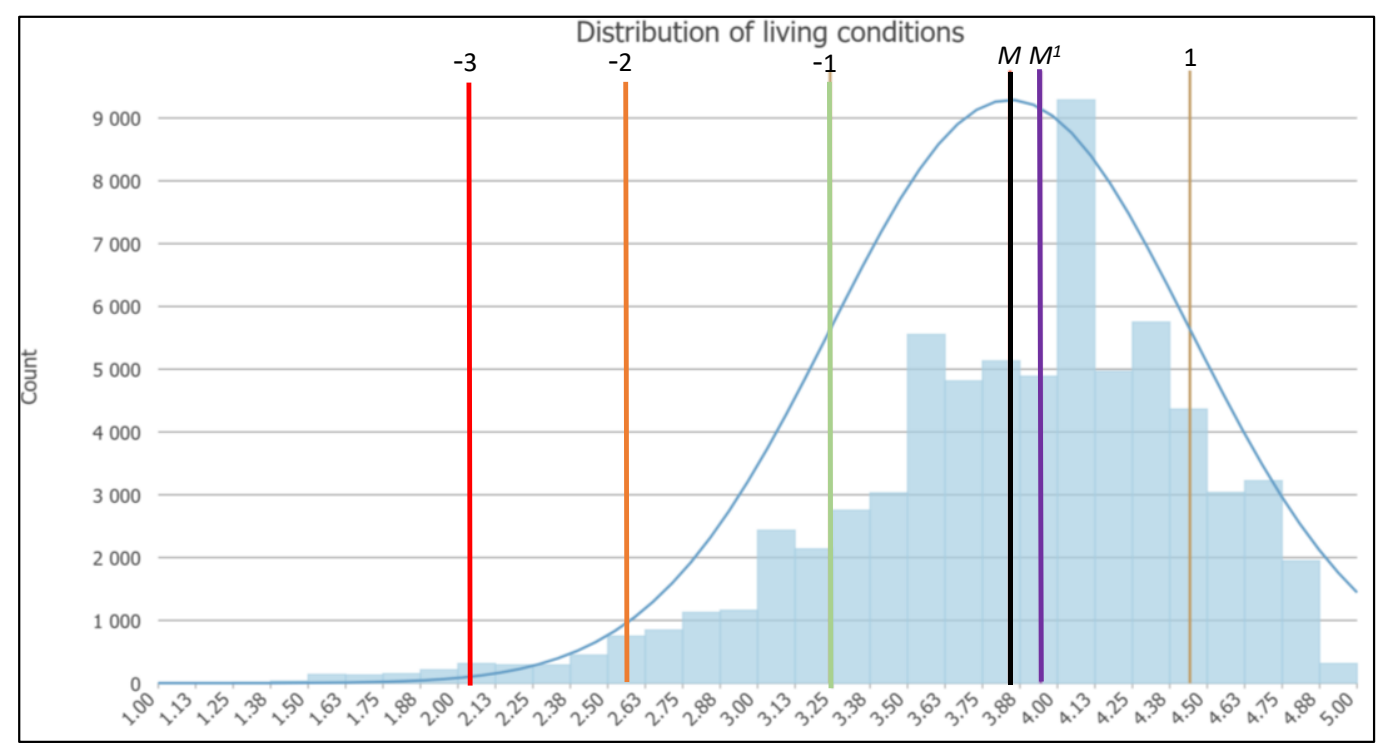

Figure 3. Distributed values of living conditions across Sweden (Mean $(\mathrm{M})=3.84$; Median $(\mathrm{M} 1)=$ 3.94; Std. Dev (SD) = 0.60; Number of grids $(n)=69,567)$.

The result of the classification and mapping of living conditions shows a distinct geographic pattern for the most vulnerable areas (i.e. red and orange areas in Figures 4-7). What is also clear is that these areas largely correspond with the Swedish Police's own 
independent assessment of exposed areas. As the map in Figure 4 shows, there is an overlap between the police's assessment and our mapping of living conditions (areas 1 and 2). It is also clear that the area boundaries for the police's assessment of exposed areas based on high levels of perceived criminal activity extend beyond the most socio-economically vulnerable areas. This may be interpreted as indicative of criminal neighborhood effects in areas adjacent to those with vulnerable living conditions, and a reduced quality of life $[30,31]$. Another possibility is that there are issues with the police's method for classifying such areas, so that they at times capture much larger areas than they should [25].

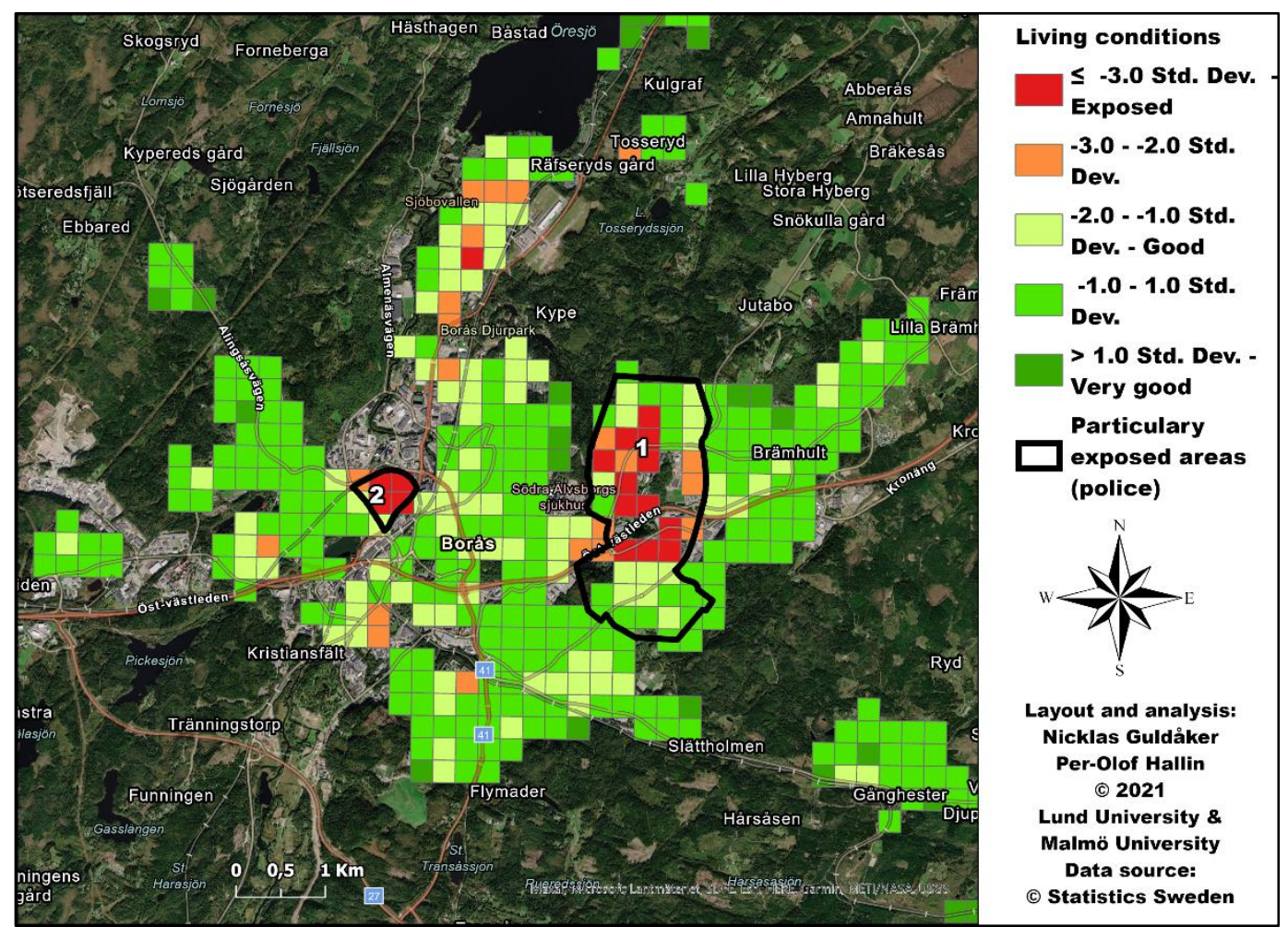

Figure 4. Living conditions and crime-exposed areas in the Swedish city of Borås.

Further, the results reveal that at least three types of areas that may be important to the police's preventive efforts in urban areas. These are: 1) expected vulnerable areas, where the police's assessment of crime-exposed areas overlaps with area grids characterized by vulnerable living conditions (Figure 4); 2) urban centers that the police mapped as crime-exposed based on their LPA mapping (Figure 5), and 3) vulnerable grid areas not classified as crime-exposed by the police (Figure 6). The first type has already been presented for Borås (Figure 4), as an example of a Swedish city with neighborhoods with vulnerable living conditions. The second type of area is associated with a classic geographical pattern characterized by high concentrations of crime in urban centers, as in the example of Gothenburg's business and communication center in Figure 5. The black marking around the urban center of Gothenburg, which represents the area identified as crimeexposed in the police's LPA mapping, relates to outdoor crime and has little to do with the usually good living conditions among the residents of this area. The third category may be important because it may indicate that there are structural conditions present that can lead the area to develop into a problem area. These areas may also be of interest if there are other underlying preventive factors and mechanisms present that are causing the low levels of crime and social unrest, despite the vulnerable socio-economic and structural conditions. Areas of this kind exist in several Swedish cities such as Västerås, Stockholm, Trollhättan and Gothenburg. A visual example of such an area - Brickebacken, in the city of Örebro - is presented in Figure 6 (area 1). The map in Figure 6 also shows a risk area (area 2) and a particularly exposed area (area 3). Areas 2 and 3 have already been 
defined by the police in accordance with the police's assessment criteria based on socioeconomic status, criminal networks and impacts on the local community.
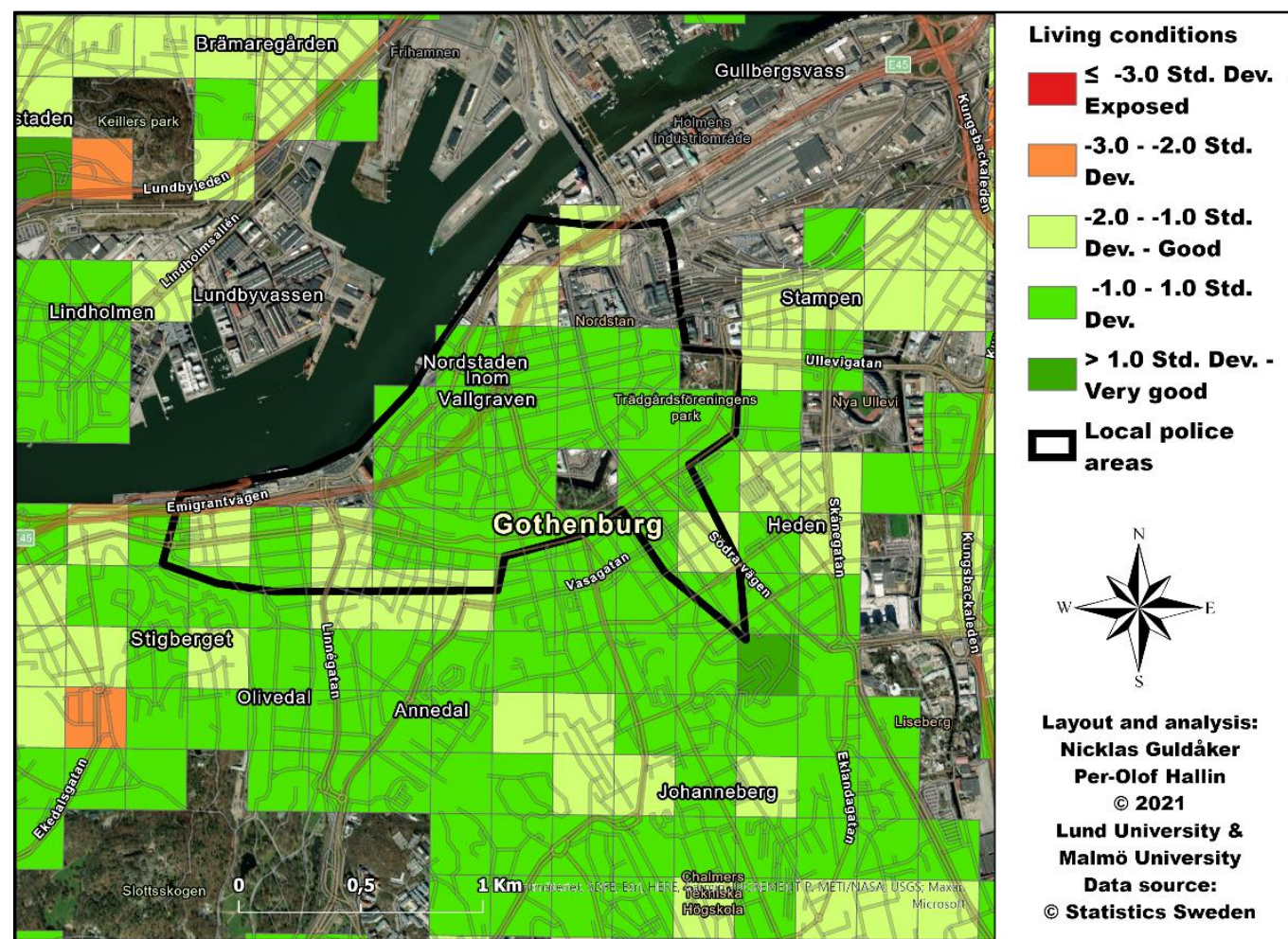

Figure 5. Urban center in Gothenburg.
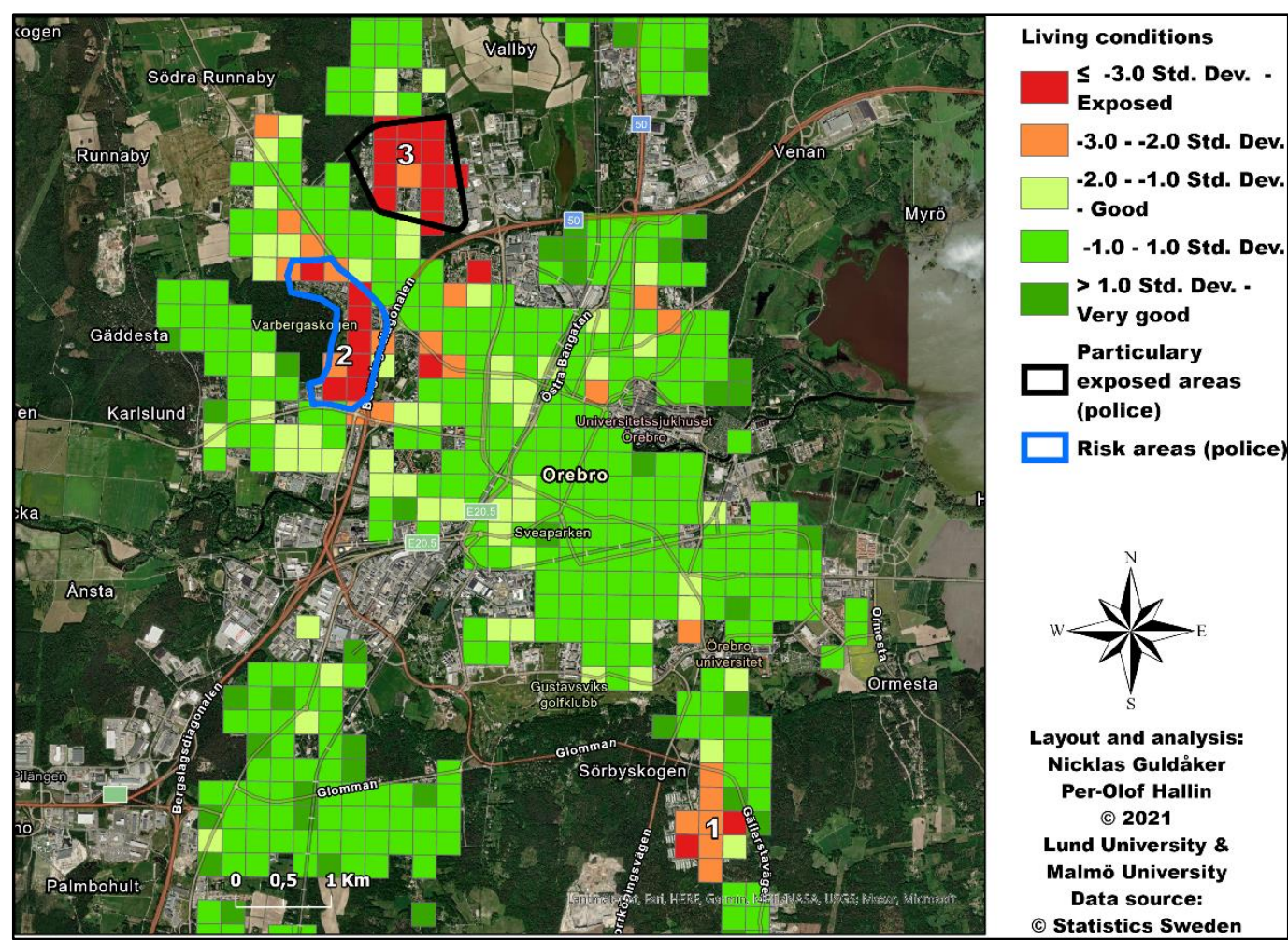

Figure 6. Brickebacken in Örebro (area 1) has vulnerable living conditions but has not been assessed by the police as an exposed area. The other areas, Varberga (area 2) and Vivalla (area 3), have been assessed as a risk area and a particularly exposed area respectively. 
As already indicated, the police's independent mapping of exposed areas largely overlaps with our mapping of vulnerable living conditions. This overlap is notable for particularly exposed areas and risk areas. As illustrated in Table 3, over 61\% (801) of the total of 1,306 intersecting grids (defined by the police as exposed areas, particularly exposed areas or risk areas) are characterized by vulnerable living conditions. Around $38 \%$ of the intersecting grids are categorized as having good living conditions, and only $0.5 \%$ as having very good living conditions. As indicated earlier in the paper, a possible explanation for these latter areas having been classified as exposed by the police assessment may be that they are experiencing neighborhood effects due to the immediate geographic proximity of established criminal territories [30,31]. These findings may also indicate that the police's experience-based and subjective assessments of exposed areas, particularly exposed areas or risk areas need to be improved.

Moreover, the results show that vulnerable living conditions characterize only $4 \%$ $(2,787)$ of the total number of 69,567 grids. Of these, about $1 \%(801)$ are included in the police's mapping of exposed areas. Viewed in terms of the model presented earlier, and the study's mapping of indexed living conditions, this also means that around $2.9 \%(1,986)$ of the national grids have vulnerable living conditions without the police having defined them as exposed areas. While $61 \%$ of the intersecting grids have vulnerable living conditions, only $2.9 \%$ of non-intersecting grids do so, indicating that vulnerable living conditions are about 20 times more common in the intersecting grids. Nevertheless, this means that there are many areas that have vulnerable living conditions, but that have not been classified as exposed areas. This is exemplified by the above-mentioned residential area (1) Brickebacken in the city of Örebro (Figure 6). Another explanation may be that the police's geographical assessment does not cover all the red and orange grids in an area with vulnerable living conditions (e.g. Varberga, area 2 in Figure 6). Even in this case, there may be reason to review the geographical boundaries established by the police. There may also be explanations based on experiences from police operations to places where many crimes have been committed or physical barriers, e.g. roads and complexes of buildings that affect the police's drawing of vulnerable areas.

Table 3. Geographical distribution of living conditions within areas assessed by the police to constitute exposed areas (Total number of intersecting grids $=1,306$, Total number of all grids $=69,567$ )

\begin{tabular}{|c|c|c|c|c|}
\hline Living conditions & $\begin{array}{l}\text { No. of intersecting } \\
\text { grids }\end{array}$ & $\begin{array}{c}\% \text { of intersecting } \\
\text { grids }\end{array}$ & Tot. no. of grids & $\begin{array}{c}\% \text { grids of } \\
\text { total }\end{array}$ \\
\hline $\begin{array}{c}\text { Vulnerable (Red } \\
\text { and orange) } \\
\leq \quad-2.0 \text { Std. Dev. }\end{array}$ & 801 & 61.33 & 2,787 & 4.01 \\
\hline $\begin{array}{l}\text { Good (Light green } \\
\text { and green) } \\
-2.0 \text { to } 1.0 \text { Std. Dev. }\end{array}$ & 499 & 38.21 & 54,978 & 79.03 \\
\hline $\begin{array}{c}\text { Very good } \\
\text { (Dark green) } \\
>\quad 1.0 \text { Std. Dev. }\end{array}$ & 6 & 0.46 & 11,802 & 16.96 \\
\hline Total & 1306 & 100 & 69,567 & 100 \\
\hline
\end{tabular}

The map in Figure 7 also elucidates the spatial connection between the mapping of living conditions, the police's assessments of vulnerable areas, and the number of children and young people resident in the area. Large cohorts with young children in vulnerable areas increase the risk of these children being recruited into criminal networks, which can also affect place-based crime patterns involving offenses such as the sale of drugs and 
violent crime [32]. The results also indicate that large cohorts of children and young people do not automatically lead to an increased risk of crime in certain urban environments, such as more affluent areas with large numbers of families with children (greener areas with large rings). Instead, this factor must be related to other stressor conditions such as poorer household finances, unemployment, more vulnerable living, and housing conditions with e.g. overcrowding and large numbers of single parent families [6]. In this context, other factors may also affect the development of an area, such as the above-mentioned informal and formal capacities of residents, property owners or other local organizations and authorities.
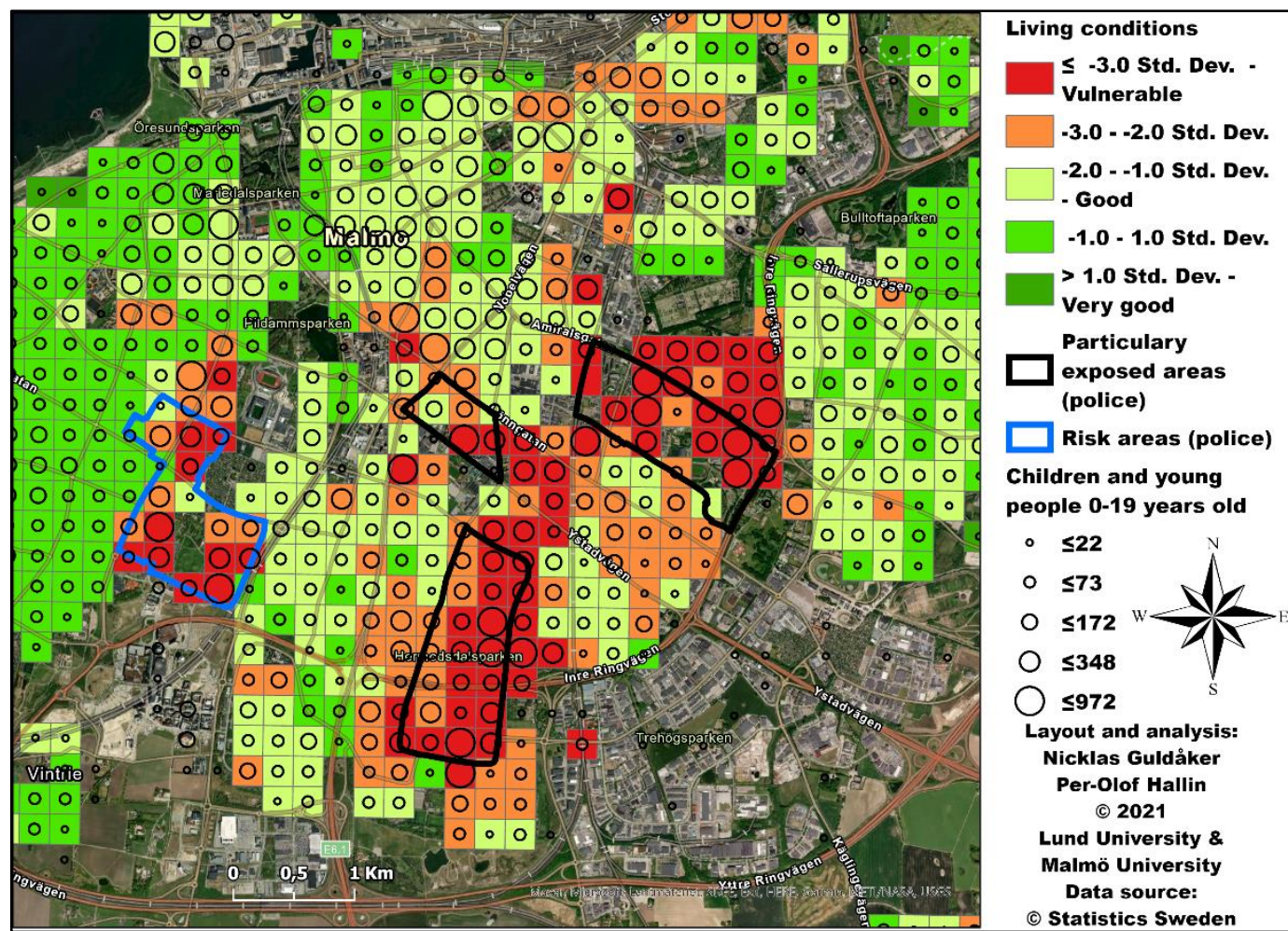

Figure 7. Living conditions, exposed areas (assessed by the police) and varying levels of resident children and young people in Malmö

\section{Discussion and conclusions}

The purpose of this paper has been to present and apply a theoretically and methodologically grounded GIS-based model for the measurement and mapping of an index of living conditions in urban residential areas across Sweden. Further, this model has been compared and evaluated in relation to the Swedish Police's assessment of crime-exposed areas.

The findings show that the results of the scientific, index-based method and model, and those of the experience-based police assessment, match to a certain extent. The overlap is relatively good, with $61 \%$ of all crime-exposed grids being characterized by vulnerable living conditions.

The results also indicate that there may be several vulnerable areas that have not been included in police's assessment of crime-exposed areas, but which have vulnerable living conditions that may have a negative effect on the development of crime. Another reason for these not having been included in the police's assessment may be that some areas with poorer living conditions have a limited crime problem according to the police's criteria. If this is the case, this represents a positive outcome, and these areas need to be studied in more detail in order to establish which local conditions are restricting the development of crime. The findings also demonstrate that certain crime-exposed areas, e.g. city centers 
and areas around transportation hubs, cannot be linked to the living conditions of the residents living there.

As a first step towards obtaining practical benefits from our modelling and mapping of living conditions, the Swedish Police have begun to use the results in their work. An initial map of living conditions, named Strategic Map 1.0, has been included in the Swedish police's GIS system in order to improve their assessment of vulnerable areas throughout Sweden. This work is also carried out with the support of several other scientifically based models, perspectives and working methods with the aim of preventing crime in vulnerable areas in numerous Swedish cities [25]. The police's list of exposed areas is updated in the context of annual assessment process, with a number of new areas being added each year, while others are removed from the list. This process is continuous, since crime levels, crime prevention activities, and people's living conditions, all change over time.

Despite the initial success of the implementation of Strategic Map 1.0, there remains a need to refine and improve the theoretical model, the index, and the method of mapping living conditions. Thus in addition to improving the accuracy of the police's work in assessing exposed areas, the modelling and mapping of the living conditions index also needs to be developed to include more dimensions that affect people's living conditions in the areas in which they live. Additional variables need to be included in the index and evaluated. Variables measuring demographic, socio-economic, health-related, and physical conditions that affect people's living conditions can be added in order to strengthen the reliability of the model and the mapped index. Also, the theoretical and analytical discussion on areas characterized by vulnerable living conditions and their relationship (or lack of a relationship) with crime exposure needs to be developed continuously and refined. Further, the competence of the police needs to be improved in order to be able to assimilate more scientifically based methods in their prevention and operational crimerelated work. In addition to supporting the police's preventive crime work, we would argue that the model and the mapping of living conditions (as an index) would also constitute a support in the work of other societal actors in vulnerable areas. Such actors include municipalities, the emergency services, real estate companies, and other regional actors or researchers that work with community planning, security, and safety in socially disadvantaged urban and rural areas. For these purposes, future studies should also include mapping, analyzing and evaluations of living conditions over time.

Author Contributions: Conceptualization, Nicklas Guldåker, and Per-Olof Hallin; methodology, Nicklas Guldåker, and Per-Olof Hallin; software, Nicklas Guldåker; validation, Nicklas Guldåker, Per-Olof Hallin, Kim Nilvall, and Manne Gerell; formal analysis, Nicklas Guldåker; investigation, Nicklas Guldåker and Per-Olof Hallin; resources, Nicklas Guldåker, and Manne Gerell; data curation, Nicklas Guldåker; writing - original draft preparation, Nicklas Guldåker; writing - review and editing, Nicklas Guldåker, Per-Olof Hallin, Kim Nilvall, and Manne Gerell; visualization, Nicklas Guldåker; project administration, Nicklas Guldåker, Per-Olof Hallin, and Kim Nilvall; funding acquisition, Per-Olof Hallin, and Kim Nilvall. All authors have read and agreed to the published version of the manuscript.

Funding: This study was funded by the Swedish Civil Contingencies Agency

Data Availability Statement: Not applicable.

Acknowledgments: This study has been conducted within the Swedish research project: Strategic GIS-based maps for collaboration and decisions on measures to counteract organized crime, social unrest, antagonistic threats and events of significance to the total defense. Special thanks to the National Operations Department at the Swedish Police (NOA), and the Swedish Civil Contingencies Agency.

Conflicts of Interest: No conflict of interest is declared by the authors. 


\section{References}

1. Wilkinson, R.G.; Pickett, K. The spirit level: Why greater equality makes societies stronger 1st ed.; Bloomsbury Publishing PLC: 2011.

2. SOU. It's about equal health. Starting points for the Commission's further work: Commission interim report on equal health.(In Swedish with the title: Det handlar om jämlik hälsa. Utgångspunkter för Kommissionens vidare arbete: Delbetänkande från Kommissionen för jämlik hälsa). Ministry of Social Affairs. 2016:55.

3. Skolverket. What affects the results in Swedish primary and lower secondary school? Knowledge overview of the importance of various factors. (In Swedish with the title: Vad påverkar resultaten i svensk grundskola? Kunskapsöversikt om betydelsen av olika faktorer). The Swedish National Agency for Education. 2009.

4. Skolverket. PISA 2015 15-year-olds' knowledge of science, reading comprehension and mathematics. (In Swedish with the title: 15-åringars kunskaper i naturvetenskap, läsförståelse och matematik). The Swedish National Agency for Education. Report 450. 2016.

5. Nilsson, A.; Estrada, F.; Bäckman, O. The unequal crime drop: Changes over time in the distribution of crime among individuals from different socioeconomic backgrounds. European Journal of Criminology 2017, 14, 586-605, doi:https://doi.org/10.1177/1477370816682979.

6. Guldåker, N.; Hallin, P.-O. Spatio-temporal patterns of intentional fires, social stress and socio-economic determinants: A case study of Malmö, Sweden. Fire Safety Journal 2014, 70, 71-80, doi:10.1016/j.firesaf.2014.08.015.

7. Guldåker, N.; Hallin, P.-O. Livsvillkor och strategisk lägesbild. In Att vända utvecklingen - Från utsatta områden till trygghet och delaktighet, Gerell M, H., P-O, Nilvall, K., Westerdahl, S, Ed.; Malmö University publications in urban studies (MAPIUS) 26; Malmö University: Malmö, 2020; Volume 26, pp. 181-188.

8. Hallin, P.-O.; Westerdahl, S. Utsatta livsvillkor. In Att vända utvecklingen: från utsatta områden till trygghet och delaktighet, Gerell, M., Hallin, P-O, Nilvall, K., Westerdahl, S, Ed.; Malmö University publications in urban studies (MAPIUS) 26; Malmö University: Malmö, 2020; pp. 24-40.

9. Nilsson, J.; Hallin, P.-O.; Tykesson Klubien, M.; Guldåker, N. Skillnader i brandförekomst inom och mellan olika storstadsområden - en statistisk analys; Department of Human Geography, Lund University. Urban studies, Malmö University: 2018.

10. Agnew, R. Foundation for a General Strain Theory of Crime and Delinquency. Criminology 1992, $30,47-87$.

11. Agnew, R. Pressured into crime. An Overview of General Strain Theory; Roxbury Publishing: 2006.

12. Merton, R.K. Social Structure and Anomie. American Sociological Review 1938, 3, 672-682.

13. Merton, R.K. Social Theory and Social Structure, Enlarged Edition ed.; The Free Press: New York, 1968.

14. Park, R.E.; Burgess, E.W. Introduction to the Science of Society. ; The University of Chicago Press.: Chicago 1921/1933.

15. Sampson, R.J.; Raudenbush, S.W.; Earls, F. Neighborhoods and violent crime: A multilevel study of collective efficacy. Science 1997, 277, 918-924, doi:10.1126/science.277.5328.918.

16. Shaw, C.R.; Zorbaugh, F.M.; McKay, H.D.; Cottrell, L.S. Delinquency areas: A study of the geographic distribution of school truants, juvenile delinquents, and adult offenders in Chicago; University of Chicago Press: Chicago, Ill., 1929; pp. xxi, 214 p.

17. Lee, Y.J.; Eck, J.E.; O, S.; Martinez, N.N. How concentrated is crime at places? A systematic review from 1970 to 2015. Crime Science 2017, 6, 6, doi:10.1186/s40163-017-0069-x. 
18. Ilijazi, V.; Milic, N.; Milidragovic, D.; Popovic, B. An Assessment of Police Officers' Perception of Hotspots: What Can Be Done to Improve Officers' Situational Awareness? ISPRS International Journal of Geo-Information 2019, 8, doi:10.3390/ijgi8060260.

19. Watson, D.; Johnson, L.M.; Pino, N.; Morgan, P. Police perceptions of residents in a high-crime area in Trinidad and Tobago: Community framing and crime wars. Criminology \& Criminal Justice 2019, 21, 3-20, doi:10.1177/1748895819858372.

20. Ratcliffe, J.H.; McCullagh, M.J. Chasing Ghosts?: Police Perception of High Crime Areas. The British Journal of Criminology 2001, 41, 330-341, doi:10.1093/bjc/41.2.330.

21. Stein, R.E.; Griffith, C. Resident and Police Perceptions of the Neighborhood: Implications for Community Policing. Criminal Justice Policy Review 2015, 28, 139-154, doi:10.1177/0887403415570630.

22. Vallejo Velazquez, M.; Kounadi, O.; Podor, A. Analysis and mapping of crime perception: A quantitative approach of sketch maps. AGILE GIScience Ser. 2020, 1, 20, doi:10.5194/agile-giss-1-20-2020.

23. Lopez, N.; Lukinbeal, C. Comparing Police and Residents' Perceptions of Crime in a Phoenix Neighborhood using Mental Maps in GIS. Yearbook of the Association of Pacific Coast Geographers 2010, 72, 33-55.

24. Sun, I.Y.; Triplett, R.A. Differential perceptions of neighborhood problems by police and residents. Policing: An International Journal of Police Strategies E Management 2008, 31, 435-455, doi:10.1108/13639510810895795.

25. Gerell, M.; Puur, M.; Guldåker, N. Swedish conditions? Characteristics of locations the Swedish police label as vulnerable. Preprint available at https://doi.org/10.31219/osf.io/3ndsw. 2021.

26. NOA. Criminal impact in the local community - A situation awareness for the development in vulnerable areas (In Swedish with the title: Kriminell påverkan i lokalsamhället - En lägesbild för utvecklingen i utsatta områden); Nationella Opertiva Avdelningen (NOA), Polismyndigheten (Swedish Police): 2019.

27. SCB. Definitions and sources for Statistics Sweden's Market Profiles (In Swedish with the title: Definitioner och källor för SCB:s Marknadsprofiler). Available online: $\quad$ https://www.scb.se/vara-tjanster/regionalastatistikprodukter/marknadsprofiler/definitioner-och-kallor-for-scbs-marknadsprofiler/ (accessed on 2021-03-10).

28. Gerell, M. Neighborhoods without community: Collective efficacy and crime in Malmö, Sweden; Malmö University: Malmö, Doctoral thesis, 2017; p. 168.

29. SCB. Urban areas in Sweden (In Swedish with the title: Tätorter i Sverige). Available online: https://www.scb.se/hittastatistik/sverige-i-siffror/miljo/tatorter-i-sverige/ (accessed on 2021-03-10).

30. Brisson, D.; Roll, S. The Effect of Neighborhood on Crime and Safety: A Review of the Evidence. Journal of Evidence-Based Social Work 2012, 9, 333-350, doi:10.1080/15433714.2010.525407.

31. Sampson, R.J.; Morenoff, J.D.; Gannon-Rowley, T. Assessing “Neighborhood Effects": Social Processes and New Directions in Research. Annual Review of Sociology 2002, 28, 443-478, doi:10.1146/annurev.soc.28.110601.141114.

32. Calderoni, F.; Maria Campedelli, G.; Comunale, T.; Marchesi, M.E.; Savona, E.U. Recruitment into organised criminal groups: A systematic review. Trends $\mathcal{E}$ Issues in Crime E Criminal Justice 2020, 1-27. 